\title{
Chronic kidney disease in the VACTERL association: clinical course and outcome
}

\author{
Sun-Young Ahn • Stanley Mendoza • George Kaplan • \\ Vivian Reznik
}

Received: 1 October 2008 /Revised: 4 December 2008 / Accepted: 5 December 2008 / Published online: 27 January 2009

(C) The Author(s) 2009. This article is published with open access at Springerlink.com

\begin{abstract}
Approximately 60\% of VACTERL (vertebral defects, anal atresia, cardiac defects, tracheoesophageal fistula with atresia, renal defects/radial limb dysplasia) patients have renal anomalies that can be associated with chronic kidney disease (CKD). With improved medical care, a large proportion of these patients survive into adulthood. Longitudinal follow-up data regarding the management of kidney disease in these children is lacking. Twelve VACTERL patients with CKD stage 2-5 and 12 age-matched controls with similar urologic anomalies and CKD [mean follow-up period 15.0 \pm 1.4 (SE) and 11.9 \pm 2.1 years, respectively] were identified in a single center. Eight VACTERL patients progressed to end-stage renal disease (ESRD) compared to four controls (66.7 vs. 33.3\%, respectively). Six VACTERL patients were dialyzed pretransplant. Of the four patients on peritoneal dialysis (PD), three had to be switched to hemodialysis due to complications, whereas two of the three controls on PD did not experience significant problems. Seven VACTERL patients underwent renal transplantation compared to four controls. Mean creatinine clearance 2 years post-transplant was $65.8 \pm$ 6.3 in VACTERL patients vs. $87.8 \pm 7.1 \mathrm{ml} / \mathrm{min}$ per $1.73 \mathrm{~m}^{2}$
\end{abstract}

S.-Y. Ahn · S. Mendoza • G. Kaplan • V. Reznik

Department of Pediatrics, University of California San Diego,

La Jolla, CA 92093, USA

G. Kaplan

Department of Surgery, Division of Urology,

Rady Children's Hospital San Diego,

San Diego, CA 92123, USA

V. Reznik $(\bowtie)$

University of California San Diego,

9500 Gilman Drive, MC 0602,

La Jolla, CA 92093-0602, USA

e-mail: vreznik@ucsd.edu in controls $(p=0.03)$. VACTERL patients had a significantly lower mean height standard deviation score than the controls $(-2.34 \pm 0.41$ vs. $-1.27 \pm 0.24$, respectively; $p<$ 0.05). Based on these results, VACTERL patients with CKD develop ESRD more frequently, experience more complications with dialysis, may have a poorer transplant outcome, and have more severe growth failure than controls.

Keywords Chronic kidney disease · Dialysis · Short stature · Transplant $\cdot$ VACTERL association

\section{Introduction}

The VATER association refers to a group of congenital malformations that includes vertebral defects, anal atresia, cardiac defects, tracheoesophageal fistula with atresia, renal defects, and radial upper limb dysplasia. The association was first described by Quan and Smith [1], and since then the description has been extended to include cardiac (C) and limb defects (L), with the resulting acronym of VACTERL $[2,3]$. Temtamy et al. suggested that the $\mathrm{V}$ in VATER could also include vascular defects, such as ventricular septal defect (VSD) and single umbilical artery (SUA) [4].

Although some cases of VACTERL association have been found to be related to chromosomal trisomy and deletion defects [5], the VACTERL association is generally not related to a chromosomal abnormality. The anomalies appear to arise from developmental abnormalities of the mesoderm of the involved organs during early embryogenesis ( $<35$ days), when the origins of the lumbosacral spine, genitourinary tract, and hindgut are located closely together [6]. There have been increasing reports of VACTERL 
association in infants of mothers with diabetes mellitus [7, 8]. The malformations in the offspring of diabetic mothers occur before the seventh gestational week, similar to the period when the developmental abnormalities responsible for VACTERL association arise, suggesting a possible causal relationship [9].

Renal anomalies are found in approximately $60-90 \%$ of VACTERL patients. Uehling et al. reported genitourinary involvement in 21 of 23 children with VATER association, including renal agenesis (seven cases), severe reflux (nine cases), crossed fused ectopia (five cases), and ureteropelvic junction obstruction (five cases) [10]. Thirteen patients in their study required more than one surgical urologic intervention. Three patients were on hemodialysis (HD) for renal failure, and one patient had a renal transplantation. Weber et al. reported renal malformations in 20 of 30 patients $(67 \%)$ with VATER association, with the most common anomalies being renal agenesis (nine cases), unilateral hypoplasia and contralateral uretero-pelvic obstruction (four cases), crossed renal ectopia (three cases), and horseshoe kidney (two cases) [11].

Although renal anomalies occur at a high frequency in VACTERL association and the management of these problems is a clinical challenge, especially in the setting of multiple other medical issues, there are almost no published reports on the clinical course of kidney disease in VACTERL association.

\section{Materials and methods}

The records of VACTERL patients with chronic kidney disease (CKD) stage 2-5 and age-matched controls with similar urologic anomalies and CKD but no VACTERL association seen at the University of California San Diego Medical Center and Rady Children's Hospital, San Diego from January 1980 to December 2005 were retrospectively reviewed. The study was approved by the Institutional Review Board at the University of California San Diego and Rady Children's Hospital, San Diego.

The diagnosis of VACTERL association was made when more than three major organ systems were involved. Exclusion criteria in this study included patients with other known disorders. All the patients underwent extensive evaluations, including ultrasounds, echocardiograms, voiding cystourethrograms, and cystoscopy.

Creatinine clearance $\left(\mathrm{CrCl}\right.$, in $\mathrm{ml} / \mathrm{min}$ per $\left.1.73 \mathrm{~m}^{2}\right)$ was estimated using the Schwartz formula [12]. The CKD staging was performed according to Kidney Disease Outcomes Quality Initiative (K/DOQI) guidelines [13]. Height standard deviation scores (SDS) were calculated by appropriate gender- or age-specific mean and standard deviation for the U.S. population using the National Health and Nutrition Examination Survey (NHANES) data of the National Center for Health Statistics and Centers for Disease Control and Prevention [14]. Since the third percentile for age and gender corresponds to a height SDS of -1.88 , the patients were categorized by height SDS < -1.88 and $>-1.88$.

Statistical analyses were performed using SPSS for Windows ver. 12.0 (SPSS, Chicago, IL). Comparison of patient characteristics between VACTERL association patients and control patients was done by the chi-square Fisher test and Student's $t$ test. A $p$ value $<0.05$ was considered to be statistically significant.

\section{Results}

Twelve VACTERL patients with CKD stage 2-5 were identified. The mean follow-up period was $15.0 \pm 1.4$ (SE) years (range 3.2-21 years), and all patients were diagnosed at birth. Six patients $(50 \%)$ were delivered prematurely. Five $(42 \%)$ were diagnosed prenatally with urological abnormalities. Among these patients, two were diagnosed with oligohydramnios, while one patient was diagnosed with polyhydramnios.

\section{Extrarenal anomalies in VACTERL patients}

Extrarenal anomalies observed in the VACTERL patients are shown in Table 1 . The most common anomaly was imperforate anus, which occurred at an incidence of $92 \%$, followed by cardiac anomalies $(67 \%)$. The incidence of vertebral and limb anomalies was 50 and $25 \%$, respectively. Limb anomalies included polydactyly, syndactyly, and reduction deficiency. Eleven patients had surgery on more than two organ systems, including abdominal surgery for imperforate anus.

Table 1 Extrarenal anomalies in VACTERL patients

\begin{tabular}{ll}
\hline Extrarenal anomalies & Number of cases (\%) \\
\hline Vertebral anomalies & $6(50)$ \\
Tracheo-esophageal fistula & $3(25)$ \\
Imperforate anus & $11(92)$ \\
Cardiac anomalies & $8(67)$ \\
Ventricular septal defect & $1(13)$ \\
Atrial septal defect & $2(25)$ \\
Patent ductus arteriosus & $2(25)$ \\
Dextrocardia & $1(13)$ \\
Septal hypertrophy & $1(13)$ \\
Limb anomalies & $3(25)$
\end{tabular}

VACTERL, Vertebral defects, anal atresia, cardiac defects, tracheoesophageal fistula with atresia, renal defects/radial limb dysplasia 
Renal and other urologic anomalies and intervention

Structural bladder anomalies were observed in $75 \%$ of the VACTERL patients (Table 2). These anomalies included duplicated, enlarged, dysplastic bladders and bladders with diverticula. Five patients had neurogenic bladders and six patients had cloacas. Most of the patients (92\%) required vesicostomies or intermittent catheterizations. Nine patients underwent vesicostomies and five had subsequent take- down with conversion to clean intermittent catheterization (CIC). Four patients had bladder augmentation and performed CIC. Eleven patients had two or more urologic surgeries. Other renal or urologic anomalies included dysplasia and reflux (five patients, 42\%) and dysplasia, reflux and obstruction (three patients, 25\%). Urethral abnormalities were also present, including stenotic urethra (two patients), urethrocutaneous fistula and chordee (one patient), and duplicated urethra (one patient).

Table 2 Renal and urologic features of VACTERL patients

\begin{tabular}{|c|c|c|c|c|c|c|}
\hline Patient & Sex & Bladder anomaly & Renal/urologic anomaly & $\begin{array}{l}\text { Urologic surgical } \\
\text { intervention }\end{array}$ & $\begin{array}{l}\text { Number of } \\
\text { urologic } \\
\text { surgeries }\end{array}$ & $\begin{array}{l}\text { Age at progression } \\
\text { to } \mathrm{CKD} \text { stage }>2 \\
\text { (years) }\end{array}$ \\
\hline Patient 1 & $\mathrm{~F}$ & Neurogenic bladder & Reflux & $\begin{array}{l}\text { Vesicostomy } \\
\text { Ureteral reimplant } \\
\text { Bladder augmentation }\end{array}$ & 3 & 3.6 \\
\hline Patient 2 & M & Enlarged bladder & $\begin{array}{l}\text { Dysplasia } \\
\text { Reflux } \\
\text { Urethrocutaneous fistula } \\
\text { Chordee } \\
\text { Rectourethral fistula }\end{array}$ & $\begin{array}{l}\text { Vesicostomy } \\
\text { Chordee release } \\
\text { Fistula repair } \\
\text { Nephrectomy }\end{array}$ & 3 & 15.8 \\
\hline Patient 3 & M & Bladder diverticulum & $\begin{array}{l}\text { Dysplasia } \\
\text { Reflux } \\
\text { Obstruction } \\
\text { Distal urethral duplication }\end{array}$ & $\begin{array}{l}\text { Vesicostomy } \\
\text { Urinary diversion }\end{array}$ & 2 & At birth \\
\hline Patient 4 & $\mathrm{~F}$ & Cloaca & $\begin{array}{l}\text { Dysplasia } \\
\text { Stenotic urethra }\end{array}$ & $\begin{array}{l}\text { Vesicostomy } \\
\text { Urinary diversion } \\
\text { Urethroplasty } \\
\text { Cloacal repair }\end{array}$ & 4 & At birth \\
\hline Patient 5 & $\mathrm{~F}$ & Cloaca & $\begin{array}{l}\text { Dysplasia } \\
\text { Obstruction }\end{array}$ & $\begin{array}{l}\text { Nephrectomy } \\
\text { Ureter reimplant } \\
\text { Bladder augmentation } \\
\text { Urinary diversion } \\
\text { Cloacal repair }\end{array}$ & 4 & 3.1 \\
\hline Patient 6 & $\mathrm{~F}$ & & $\begin{array}{l}\text { Dysplasia } \\
\text { Reflux }\end{array}$ & & 0 & At birth \\
\hline Patient 7 & $\mathrm{~F}$ & $\begin{array}{l}\text { Neurogenic bladder } \\
\text { Cloaca }\end{array}$ & $\begin{array}{l}\text { Dysplasia } \\
\text { Reflux }\end{array}$ & $\begin{array}{l}\text { Vesicostomy } \\
\text { Urinary diversion }\end{array}$ & 3 & At birth \\
\hline Patient 8 & $\mathrm{~F}$ & $\begin{array}{l}\text { Duplicated bladder } \\
\text { Cloaca }\end{array}$ & $\begin{array}{l}\text { Dysplasia } \\
\text { Reflux }\end{array}$ & $\begin{array}{l}\text { Urinary diversion } \\
\text { Cloacal repair }\end{array}$ & 2 & At birth \\
\hline Patient 9 & $\mathrm{~F}$ & $\begin{array}{l}\text { Deformed bladder } \\
\text { Cloaca }\end{array}$ & $\begin{array}{l}\text { Dysplasia } \\
\text { Reflux }\end{array}$ & $\begin{array}{l}\text { Vesicostomy } \\
\text { Cloacal repair }\end{array}$ & 2 & At birth \\
\hline Patient 10 & M & Neurogenic bladder & $\begin{array}{l}\text { Dysplasia } \\
\text { Reflux } \\
\text { Bulbar urethral stricture } \\
\text { Chordee }\end{array}$ & $\begin{array}{l}\text { Vesicostomy } \\
\text { Urinary diversion } \\
\text { Bladder augmentation } \\
\text { Release of chordee } \\
\text { Urethral stricture repair }\end{array}$ & 6 & 10.3 \\
\hline Patient 11 & $\mathrm{~F}$ & $\begin{array}{l}\text { Neurogenic bladder } \\
\text { Cloaca }\end{array}$ & & $\begin{array}{l}\text { Vesicostomy } \\
\text { Cloacal repair }\end{array}$ & 2 & At birth \\
\hline Patient 12 & $\mathrm{~F}$ & $\begin{array}{l}\text { Bladder diverticulum } \\
\text { Neurogenic bladder } \\
\text { Colovesical fistula }\end{array}$ & $\begin{array}{l}\text { Dysplasia } \\
\text { Obstruction } \\
\text { Reflux }\end{array}$ & $\begin{array}{l}\text { Pyeloplasty } \\
\text { Nephrectomy } \\
\text { Vesicostomy } \\
\text { Bladder augmentation } \\
\text { Closure of fistula }\end{array}$ & 5 & 12.4 \\
\hline
\end{tabular}

F, Female; M, male; CKD, chronic kidney disease 
Dialysis modalities

Six VACTERL patients required dialysis. Two (33.3\%) were started on HD due to severe adhesions from more than five previous abdominal surgeries. Four patients, who had two or fewer previous abdominal surgeries, were initially started on peritoneal dialysis (PD), but three were switched to $\mathrm{HD}$ due to complications. One patient developed a diaphragmatic leak 3 months after starting PD and was switched to HD. The second patient underwent another abdominal surgery 4 months after starting PD and was switched to HD; she was unable to go back to PD due to adhesions after the surgery. The third patient also had another abdominal surgery after starting PD and several episodes of peritonitis that may have aggravated preexisting adhesions; she was eventually switched to HD in 1 year. Peritoneal dialysis was not attempted again since these patients were transplanted within 9 months after starting HD. The one PD patient who was successfully dialyzed had previously undergone only one abdominal surgery (gastrostomy).

\section{Renal Transplant}

Seven VACTERL patients were transplanted. Five patients $(71.4 \%)$ received a living-related donor transplant; two were pre-emptive transplants. Two other patients received a deceased donor transplant. One patient on HD was unable to receive a transplant until the end of the study period. The time from diagnosis of end-stage renal disease (ESRD) to renal transplant was $9.1 \pm 3.2$ months. The mean $\mathrm{CrCl}$ immediately post-transplant, 2 years post-transplant, and 5 years post-transplant was $88.4 \pm 8.4,65.8 \pm 6.3$, and $47.8 \pm$ $6.4 \mathrm{ml} / \mathrm{min}$ per $1.73 \mathrm{~m}^{2}$, respectively (Table 3). Two patients had graft failure.
Growth in VACTERL patients

Eight $(67 \%)$ VACTERL patients had a height SDS $<-1.88$. For all of these patients (male:female, 1:7), growth hormone (GH) achieved a significant improvement in height SDS: from $-3.4 \pm 0.4$ to $-2.6 \pm 0.5$ within 2 years $(p<0.05)$. The mean age of the VACTERL patients at initiation of the GH treatment was $11.3 \pm 0.9$ years. One patient was at CKD stage 4 , six patients at stage 3 , and one patient at stage 2 at the initiation of GH treatment.

Comparison between VACTERL and control patients

VACTERL patients and age-matched controls with similar urologic anomalies but no VACTERL association were compared (Table 4). The mean follow-up period was similar between the two groups ( $15.0 \pm 1.4$ vs. $11.9 \pm 2.1$ years, $p=0.23$ ). Nine control patients had bladder involvement and four had neurogenic bladder, similar to the VACTERL patients. More patients in the VACTERL group than in the control group reached ESRD during the study period, but this difference was not statistically significant. Five of six VACTERL patients were ultimately placed on HD, while only one of the three CKD control patients was treated with HD. VACTERL patients experienced several complications during PD, including diaphragmatic leak and severe abdominal adhesions that required them to switch to HD; in comparison, none of the control patients experienced complications that required them to switch dialysis modalities. Seven VACTERL patients versus four controls were transplanted, and the mean $\mathrm{CrCl} 2$ years post-transplant was $65.8 \pm 6.3$ vs. $87.8 \pm 7.1 \mathrm{ml} / \mathrm{min}$ per $1.73 \mathrm{~m}^{2}(p=0.03)$, respectively. VACTERL patients were significantly shorter than control patients, with the height SDS for all VACTERL patients and control patients being $-2.34 \pm 0.41$ vs.

Table 3 Mean serum creatinine levels $(\mathrm{mg} / \mathrm{dl})$ and creatinine clearance $\left(\mathrm{ml} / \mathrm{min}\right.$ per $\left.1.73 \mathrm{~m}^{2}\right)$ post-transplant

\begin{tabular}{|c|c|c|c|c|c|}
\hline \multirow[t]{2}{*}{ Patient } & \multirow{2}{*}{$\begin{array}{l}\text { Age at transplant } \\
\text { (years) }\end{array}$} & \multicolumn{3}{|c|}{ Mean serum creatinine $(\mathrm{CrCl})$} & \multirow[t]{2}{*}{ Bladder anomaly } \\
\hline & & $\begin{array}{l}\text { Immediately post- } \\
\text { transplant }\end{array}$ & $\begin{array}{l}2 \text { years post- } \\
\text { transplant }\end{array}$ & $\begin{array}{l}5 \text { years post- } \\
\text { transplant }\end{array}$ & \\
\hline Patient 2 & 18.4 & $1.8(53.5)$ & $1.8(53.5)$ & $\mathrm{N} / \mathrm{A}$ & Enlarged bladder \\
\hline Patient 3 & 2.9 & $0.4(114.8)$ & $0.5(97.4)$ & $0.9(68.1)$ & Bladder diverticulum \\
\hline Patient 4 & 3.8 & $0.6(81.6)$ & $0.9(66)$ & $1.4(47.1)$ & Cloaca \\
\hline Patient $5^{\mathrm{a}}$ & 11.1 & $0.8(89.4)$ & $1.2(66.9)$ & $1.5(54.8)$ & Cloaca \\
\hline Patient $7^{\mathrm{b}}$ & 7.7 & $0.6(94.3)$ & $1.4(44.5)$ & $2.1(33.8)$ & Cloaca \\
\hline Patient 8 & 1.6 & $0.4(113.4)$ & $0.7(71.7)$ & $\mathrm{N} / \mathrm{A}$ & Cloaca \\
\hline Patient 11 & 8.1 & $0.8(71.5)$ & $1.0(60.8)$ & $1.9(35.3)$ & Cloaca \\
\hline Mean $\mathrm{CrCl}( \pm \mathrm{SE})\left(\mathrm{ml} / \mathrm{min}\right.$ per $\left.1.73 \mathrm{~m}^{2}\right)$ & & $88.4 \pm 8.4$ & $65.8 \pm 6.3$ & $47.8 \pm 6.4$ & \\
\hline
\end{tabular}

$\mathrm{CrCl}$, Creatinine clearance; N/A, not available due to patient being less than 5 years post-transplant

${ }^{a}$ Patient developed graft failure 7 years 9 months after transplant

${ }^{\mathrm{b}}$ Patient developed graft failure 8 years after transplant 
Table 4 Comparison between VACTERL and chronic kidney disease control patients with urologic anomalies

\begin{tabular}{|c|c|c|c|}
\hline $\begin{array}{l}\text { Characteristics of } \\
\text { study cohort }\end{array}$ & VACTERL & Controls & $p$ value \\
\hline Male:female & $3: 9$ & $5: 7$ & \\
\hline $\begin{array}{l}\text { Mean follow-up } \\
\text { (years) }\end{array}$ & $15.0 \pm 1.4$ & $11.9 \pm 2.1$ & 0.23 \\
\hline $\begin{array}{l}\text { Mean age at diagnosis } \\
\text { of CKD stage }>2 \\
\text { (years) }\end{array}$ & $3.8 \pm 1.7$ & $9.4 \pm 1.8$ & 0.03 \\
\hline $\begin{array}{l}\text { Number of ESRD } \\
\text { patients }\end{array}$ & $8 / 12(67 \%)$ & $4 / 12(33 \%)$ & 0.22 \\
\hline $\begin{array}{l}\text { Mean age of reaching } \\
\text { ESRD (years) }\end{array}$ & $8.5 \pm 2.5$ & $9.3 \pm 2.7$ & 0.82 \\
\hline \multirow[t]{2}{*}{ Dialysis modality } & $\begin{array}{l}\text { Hemodialysis: } 2 \\
\text { patients }\end{array}$ & $\begin{array}{l}\text { Peritoneal } \\
\text { dialysis: } 2 \\
\text { patients }\end{array}$ & \\
\hline & $\begin{array}{l}\text { Peritoneal dialysis, } \\
\text { then hemodialysis: } \\
3 \text { patients } \\
\text { Peritoneal dialysis: } \\
1 \text { patient }\end{array}$ & $\begin{array}{l}\text { Hemodialysis: } \\
1 \text { patient }\end{array}$ & \\
\hline $\begin{array}{l}\text { Number of transplant } \\
\text { patients }\end{array}$ & $7 / 12(58 \%)$ & $4 / 12(33 \%)$ & \\
\hline $\begin{array}{l}\text { Living-related donor } \\
\text { transplants }\end{array}$ & $5(71.4 \%)$ & $3(75 \%)$ & 1.0 \\
\hline \multicolumn{4}{|c|}{ Mean $\mathrm{CrCl}\left(\mathrm{ml} / \mathrm{min}\right.$ per $\left.1.73 \mathrm{~m}^{2}\right)$} \\
\hline 6 months & $72.3 \pm 10.8$ & $100.7 \pm 8.4$ & 0.1 \\
\hline 2 years & $65.8 \pm 6.3$ & $87.8 \pm 7.1$ & 0.03 \\
\hline
\end{tabular}

Values are given as mean \pm standard error unless indicated otherwise

$-1.27 \pm 0.24(p=0.03)$ prior to $\mathrm{GH}$ use. Eight VACTERL patients were on $\mathrm{GH}$, while one control patient was treated with GH.

\section{Discussion}

Renal anomalies are found at a high frequency in VACTERL association; there are, however, very few reports on the renal course in this subset of the population and especially in pediatric patients. We followed our subjects over an extended period of time $(15.0 \pm 1.4$ years $)$ and have described their renal/urologic anomalies, various aspects of their $\mathrm{CKD}$, dialysis modality, and renal transplant course.

Twelve patients developed CKD stage $2-5$ during the study period. Interestingly, we noted that although in VACTERL association there is a similar ratio of males to females (52 vs. $48 \%$ ) [15], the patients who had CKD in our study were predominantly female $(75 \%)$.

Multi-organ involvement in VACTERL patients greatly complicates medical care. Weber et al. studied 30 infants with VATER association and reported that 21 of the patients
(70\%) required major surgeries on two organ systems, while one patient required major surgeries on three organ systems [11]. Our patients also had multiple congenital anomalies, and 11 underwent surgery on more than two organ systems. These extra-renal anomalies can complicate the renal course in VACTERL patients. For example, due to intraabdominal adhesions from previous surgeries, most of the VACTERL patients in our study were on HD rather than PD.

Most VACTERL patients (92\%) in our study had bladder involvement that required urologic interventions, such as vesicostomies, intermittent catheterizations, bladder augmentation or urinary diversion. The bladder anomalies were also accompanied by other complex urological abnormalities (Table 2), similar to those reported in other studies [10, 11]. These included urethral abnormalities, such as stenotic urethra, urethrocutaneous fistula, and chordee, and duplicated urethra. Fernbach [16] reported that eight of 20 VATER patients in their study had urethral anomalies, which included megalourethra, urethral duplication, anterior urethral valve, hypospadias, and congenital stricture. Due to the high incidence of urethral anomalies, the author recommended doing a voiding cystourethrogram on all males with VATER association even when clinical symptoms are not present. Since $75 \%$ of the VACTERL patients with CKD in our study were female and most had significant bladder anomalies, a complete urologic evaluation should be considered for all VACTERL patients with CKD.

Eight VACTERL patients progressed to ESRD at a mean age of $8.5 \pm 2.5$ years. Six patients were started on dialysis. Peritoneal dialysis was initially chosen as the dialysis modality for most of the VACTERL patients due to the many advantages it has for pediatric patients, including greater freedom to ambulate and less interruption of daily activities. Two patients were treated with HD only due to multiple abdominal surgeries; three PD patients were switched to HD due to complications, such as intraabdominal adhesions and diaphragmatic leak. It appears that HD is the preferred modality for VACTERL patients due to the high incidence of intra-abdominal surgeries and the potential for adhesions preventing successful PD. In accordance with our study, Uehling et al. also reported that the ESRD patients in their study also all underwent HD, although no mention is made on whether these patients required $\mathrm{HD}$ due to complications that prevented them from undergoing PD [10].

Seven VACTERL patients in our study were transplanted. Patients who have congenital urologic anomalies have been shown to be at increased risk for urinary tract infection, surgical complications, graft dysfunction, and graft loss [1719]. There are conflicting reports on the management of the lower urinary tract before and after transplantation. Alfrey et al. reported that bladder augmentation before transplant caused increasing hydronephrosis and infection and sug- 
gested takedown of bladder augmentation before transplant [20]. Other studies, however, have shown that urinary tract reconstruction before transplantation is safe [21-23]. Koo et al. studied 18 patients with severe dysfunctional lower urinary tract anomalies that included posterior urethral valves, urogenital sinus anomalies, prune-belly syndrome, complete bladder duplication, and ureterocele [22]. Eleven patients underwent bladder augmentation or continent urinary diversion, while two had an intestinal conduit and five had a transplant into the native bladder. These researchers reported a patient survival of $100 \%$ and an allograft survival of $81 \%$ during a 4.4 -year follow-up period, which were similar to the values of all the children who underwent renal transplantation in their center. They therefore concluded that renal transplantation in patients with lower urinary tract dysfunction was successful and that bladder reconstruction could be safely performed before and after transplant. In our study, all seven patients who underwent renal transplant had severe lower urinary tract anomalies, and six patients underwent urinary reconstruction prior to transplant. Among the five patients with $\mathrm{CrCl}<$ $70 \mathrm{ml} / \mathrm{min}$ per $1.73 \mathrm{~m}^{2}$ at 2 years post-transplant (Table 3), four had a cloaca and one had an enlarged bladder; the other two patients with $\mathrm{CrCl}>70 \mathrm{ml} / \mathrm{min}$ per $1.73 \mathrm{~m}^{2}$ had a cloaca and a bladder diverticulum. Although patient 3 with only bladder diverticulum had the best post-transplant function at 2 years $\left(97.4 \mathrm{ml} / \mathrm{min}\right.$ per $\left.1.73 \mathrm{~m}^{2}\right)$ and 5 years $(68.1 \mathrm{ml} / \mathrm{min}$ per $1.73 \mathrm{~m}^{2}$ ), our study group is much too small to draw any conclusions about whether severe VACTERL bladder anomalies may have contributed to poor transplant graft function and outcome. Patients 5 and 7, both with cloaca, had graft failure by 8 years ( $71 \%$ graft survival by 8 years).

VACTERL patients have been noted to have growth deficiency. In a study of 31 VATER patients, $45 \%$ of the patients showed postnatal growth deficiency of at least -2 SDS for the first 3 years of life or beyond [24]. Severe cardiac defect was correlated to the growth deficiency in nine patients, but no cause for the growth deficiency in the other patients was noted. Khadilkar et al. found that VATER patients did not demonstrate GH deficiency and did not appear to have pituitary dysfunction [25]. Only one of their VATER patients had vertebral anomalies, and so this would not have explained the short stature. Unlike the VACTERL patients in our study, however, patients in the study by Khadilkar et al. did not have CKD.

In our study, eight $(67 \%)$ VACTERL patients had a height SDS $<-1.88$. This was a significantly higher percentage compared to the North American Pediatric Renal Trials and Collaborative Studies (NAPRTCS) database, where CKD patients with a height SDS $\leq-1.88$ comprised $36.9 \%$ of the patient cohort [26]. Late treatment with GH may have been a factor in the short stature of the VACTERL patients since they were treated with GH late in childhood (mean age at GH initiation $11.3 \pm 0.9$ years). Since 9/12 patients had CKD stage $>2$ when less than 4 years old (Table 2), earlier treatment with GH may have resulted in an improved height SDS. Faster progression of $\mathrm{CKD}$ and late treatment with GH could be the reason for the poorer growth in VACTERL patients compared to that in the control patients prior to $\mathrm{GH}$ use.

Other factors that could have contributed to the short stature in VACTERL patients include feeding difficulties, especially for patients with T-E fistula, multiple surgeries, CKD stage, and cardiovascular anomalies. However, we could not find a significant correlation between these factors and short stature for our patients. One limitation of our study is the small number of patients. With a larger study number, a more apparent cause may be uncovered.

In order to observe the effect that the VACTERL association had on the course of renal disease, we identified age-matched controls with similar urologic anomalies to the VACTERL patients but without VACTERL association. There was no significant difference in the number of patients with bladder anomalies between the control and VACTERL patients, and the bladder anomalies were similar in nature. Therefore, bladder anomalies did not appear to be responsible for the higher frequency of ESRD and poor outcome after renal transplantation in VACTERL patients. Furthermore, Khositseth et al. reported no difference in graft function between kidney transplant recipients with obstructive and reflux uropathy and the controls over a 10 -year period [27]. This may indicate that factors other than urologic anomalies may influence graft function in VACTERL patients, especially since these patients had multiple other medical issues.

The small number of subjects limited our ability to determine the prognostic factors for short stature and development of graft dysfunction. More data would be required to obtain statistically significant conclusions.

With improving medical care, more VACTERL patients are surviving into adulthood. There are, however, very few reports on the renal course and complications of VACTERL association patients. This population has an array of complex anomalies that make treating CKD difficult. Describing the clinical course, treatment, and outcome of kidney disease in VACTERL association patients may help clinicians treat this population. Further study of the various complications that can arise during treatment of VACTERL patients, the modes of intervention that may be required, and the timing of these interventions may lead to improved treatment and outcomes.

Acknowledgments We gratefully acknowledge the invaluable assistance provided by Dina MacDonald, RN. 


\section{Conflicts of interest None.}

Open Access This article is distributed under the terms of the Creative Commons Attribution Noncommercial License which permits any noncommercial use, distribution, and reproduction in any medium, provided the original author(s) and source are credited.

\section{References}

1. Quan L, Smith DW (1973) The VATER association. Vertebral defects, Anal atresia, T-E fistula with esophageal atresia, radial and renal dysplasia: a spectrum of associated defects. J Pediatr 82 (1):104-107

2. Kaufman RL (1973) Birth defects and oral contraceptives. Lancet 1(7816): 1396

3. Nora AH, Nora JJ (1975) A syndrome of multiple congenital anomalies associated with teratogenic exposure. Arch Environ Health 30(1):17-21

4. Temtamy SA, Miller JD (1974) Extending the scope of the VATER association: definition of the VATER syndrome. J Pediatr 85(3):345-349

5. McNeal RM, Skoglund RR, Francke U (1977) Congenital anomalies including the VATER association in a patient with del (6)q deletion. J Pediatr 91(6):957-960

6. Gilbert E, Optiz J (1979) Renal involvement in genetic-hereditary malformation syndromes. In: Hamburger J, Crosnier J, Grunfeld JP (eds) Nephrology. John Wiley, New York, pp 909-944

7. Boutte P, Valla JS, Lambert JC, Tordjman C, Berard E, Mariani R (1985) The Vater association in a newborn infant of a diabetic mother. Pediatrie 40(3):219-222

8. Castori M, Rinaldi R, Capocaccia P, Roggini M, Grammatico P (2008) VACTERL association and maternal diabetes: a possible causal relationship? Birth Defects Res A Clin Mol Teratol 82 (3):169-172

9. Mills JL, Baker L, Goldman AS (1979) Malformations in infants of diabetic mothers occur before the seventh gestational week. Implications for treatment. Diabetes 28(4):292-293

10. Uehling DT, Gilbert E, Chesney R (1983) Urologic implications of the VATER association. J Urol 129(2):352-354

11. Weber TR, Smith W, Grosfeld JL (1980) Surgical experience in infants with the VATER association. J Pediatr Surg 15(6):849-854

12. Schwartz GJ, Haycock GB, Edelmann CM Jr, Spitzer A (1976) A simple estimate of glomerular filtration rate in children derived from body length and plasma creatinine. Pediatrics 58 (2):259-263

13. Eknoyan G, Levin N (2002) K/DOQI clinical practice guidelines for chronic kidney disease: evaluation, classification, and stratification. Am J Kidney Dis 39[2 Suppl 1]:S14-S214

14. Centers for Disease Control and Prevention (2000). National Center for Health Statistics. National Health and Nutrition Examination Survey Data. Available at: http://www.cdc.gov/ nchs/about/major/nhanes

15. Weaver DD, Mapstone CL, Yu PL (1986) The VATER association. Analysis of 46 patients. Am J Dis Child 140(3):225-229

16. Fernbach SK (1991) Urethral abnormalities in male neonates with VATER association. AJR Am J Roentgenol 156(1):137-140

17. Churchill BM, Sheldon CA, McLorie GA, Arbus GS (1988) Factors influencing patient and graft survival in 300 cadaveric pediatric renal transplants. J Urol 140(5 Pt 2):1129-1133

18. Mochon M, Kaiser BA, Dunn S, Palmer J, Polinsky MS, Schulman SL, Flynn JT, Baluarte HJ (1992) Urinary tract infections in children with posterior urethral valves after kidney transplantation. J Urol 148(6):1874-1876

19. Adams J, Mehls O, Wiesel M (2004) Pediatric renal transplantation and the dysfunctional bladder. Transpl Int 17(10):596-602

20. Alfrey EJ, Salvatierra O Jr, Tanney DC, Mak R, Scandling JD, Dafoe DC, Hammer GB, Orlandi PD, Page L, Conley SB (1997) Bladder augmentation can be problematic with renal failure and transplantation. Pediatr Nephrol 11(6):672-675

21. DeFoor W, Minevich E, McEnery P, Tackett L, Reeves D, Sheldon C (2003) Lower urinary tract reconstruction is safe and effective in children with end stage renal disease. J Urol 170(4 Pt 2):1497-1500

22. Koo HP, Bunchman TE, Flynn JT, Punch JD, Schwartz AC, Bloom DA (1999) Renal transplantation in children with severe lower urinary tract dysfunction. J Urol 161(1):240-245

23. Sheldon CA, Gonzalez R, Burns MW, Gilbert A, Buson H, Mitchell ME (1994) Renal transplantation into the dysfunctional bladder: the role of adjunctive bladder reconstruction. J Urol 152(3):972-975

24. Mapstone CL, Weaver DD, Yu PL (1986) Analysis of growth in the VATER association. Am J Dis Child 140(4):386-390

25. Khadilkar VV, Cameron FJ, Stanhope R (1999) Growth failure and pituitary function in CHARGE and VATER associations. Arch Dis Child 80(2):167-170

26. Seikaly MG, Salhab N, Gipson D, Yiu V, Stablein D (2006) Stature in children with chronic kidney disease: analysis of NAPRTCS database. Pediatr Nephrol 21(6):793-799

27. Khositseth S, Askiti V, Nevins TE, Matas AJ, Ingulli EG, Najarian JS, Gillingham KJ, Chavers BM (2007) Increased urologic complications in children after kidney transplants for obstructive and reflux uropathy. Am J Transplant 7(9):2152-2157 